\title{
TURIZMO VEIKSNYS UGDANT MOKYKLINIO AMŽIAUS VAIKUS PASITELKUS PAVELDA
}

\author{
RASA Č́PAITIENE ${ }^{1}$
}

Lietuvos istorijos institutas

\begin{abstract}
ANOTACIJA
Remiantis interpretacijos klasiko F. Tildeno suformuotais paveldo interpretacijos principais bei jų plètote vèlesnių autorių darbuose, straipsnyje aptariami ir analizuojami ugdymo, pasitelkus paveldą, mokykliniame amžiuje esminiai siekiniai ir priemonès. Tekste atskleidžiama mokymosi, pasitelkus paveldą mokykliniame amžiuje, specifika, atsižvelgiant tiek ị amžiaus tarpsnių psichologiją, tiek ir ị geografinị vaiko gyvenamosios vietos veiksnį. Daroma išvada, kad lyginant su kitomis šalimis šioje srityje Lietuvoje kol kas nuveikta nepakankamai, todèl būtina edukaciją, pasitelkus paveldą, nuosekliai populiarinti, o jos veiklas integruoti ị formalią švietimo sistemą. Be to, pateikiama praktinių patarimų, kaip efektyviau vykdyti Lietuvos vaikų ir jaunimo paveldo pažinimo darbą, akcentuojant neformalių veiklų, ypač vietinio ir regioninio turizmo, reikšmę.

PAGRINDINIAI ŽODŽIAI: paveldas, ugdymas, interpretacija, turizmas, moksleiviai.
\end{abstract}

JEL KLASIFIKACIJA: I.12.120.

DOI:

Ivadas

Straipsnio problema. Kultūros ir gamtos paveldas - tai ne tik iškiliausi dailès ar architektūros paminklai, materialus bei dvasinis šalies turtas, bet ir vienas iš teritorinę bendruomenę politine tauta paverčiančio istorinio proceso šaltinių bei veiksnių. Iš esmès jis net gali būti laikomas visuomenę vienijančiu pagrindu, be kurio nebūtų ịmanomas lokalios, regioninès ir nacionalinès kultūros puoselèjimas, perteikimas bei plètra. Jo dèka užmezgami ryšiai tarp kartų, perduodamos ir ịtvirtinamos dvasinès vertybès, patriotizmas, skatinamas prisirišimas prie gimtosios vietos. Tačiau svarbiausia, kad materialios ir nematerialios kultūros vertybès padeda atsakyti ị kiekvienam fundamentalu klausimą, kas aš esu, bei dar fundamentalesnị - kas esame mes, taigi kuria ir palaiko kolektyvinị tapatumą (Ashworth, Howard, 2008: 83-107). Tačiau tai anaiptol nèra savaiminis procesas. Vien fizinio šių vertybių egzistavimo ar nekritiško tradicijų atkartojimo nepakanka, kad suvoktume jų tikrają reikšmę. Paveldas yra nebylus, t. y. pats apie save nekalba, tad negali atskleisti savo skleidžiamos žinios ir verčių (Čepaitienè, 2010: 300), todèl jo tinkamas ,prakalbinimas“ tampa svarbiu uždaviniu siekiant aukščiau išvardytų tikslų. Ypač tai svarbu gamtos ar kultūros vertybių, kaip ir kasdienės artimosios aplinkos, pragmatiško (iš)eikvojimo, apleidimo, teršimo ar net niokojimo atvejais, kas liudija ne tik negebejjimą įžvelgti ir ịvertinti jų socialinès reikšmès, neišlavintą estetinį skonį, bet ir didesnès atsakomybės už save ir kitus stoką. Todèl paveldosaugos nuostatų populiarinimas visuomeneje apima ne tik bendruosius vandalizmo prevencijos ar aplinkosauginio sąmoningumo ugdymo klausimus, bet yra glaudžiai susijęs ir su platesnėmis žmogaus bei bendruomenių vystymosi ir darnios raidos temomis (Heritage Education Handbook, 1986: 12).

Kadangi kultūros perdavimo procesai savaime nevyksta, jų kryptingumą, sklandumą ir kokybę nulemia tik nuolatinès ir sutelktos socializacijos bei ugdymo pastangos. Tačiau paradoksalu, kad formalusis švieti-

1 Rasa Čepaitienè - kultūros istorikè, daktare (humanitariniai mokslai), Lietuvos istorijos instituto vyresnioji mokslo darbuotoja Moksliniai interesai: paveldosaugos teorijos, istorinès atminties studijos, miestų tyrimai, sovietinè kultūra ir posovietinè transformacija El. paštas: geokdepe@gmail.com 
mas, pradedant darželiais ir baigiant aukštosiomis mokyklomis, ir ugdymas, pasitelkus paveldą, bent jau Lietuvoje, iki šiol nèra užmezgę glaudesnių tarpusavio ryšių, kurių ịtvirtinimas ir puoselëjimas, be abejonès, būtų reikšmingas šiandien sociokultūrinę krizę išgyvenančiai mūsų visuomenei. Visuomenei, kurioje ịsigalèjusios neoliberalios vertybinès nuostatos ir postmodernusis reliatyvizmas nepastebimai, bet nuosekliai ardo stabilų kolektyvinį tapatumą ir bendražmogiškosios bei kultūrinès bendrystès saitus, kuriais ir remiasi šeima, bendruomenè, tauta, valstybè. Todėl neišvengiamai silpsta ir nacionalinio tapatumo išlaikymo pastangos, mąžta piliečiu - savos valstybės patriotu - skaičius.

Kultūros paveldas, kokią reikšmę šiai sąvokai šiandien besuteiktume ar kokius objektus ị ją beįtrauktume, visada siejamas su kažkuo aiškiai identifikuojamu, pozityviai vertinamu ir savu, o Lietuvai, metams bėgant patyrusiai tiek karų, okupacijų, svetimų politinių santvarkų ir ideologijų primestos tvarkos, iki šiol sunku apibrèžti, kas gi yra tas „savas“ paveldas. Lenkakalbẻ dvarų kultūra vis dar atrodo „itartina“ ir sunkiai įsiliejanti ị didiji istorinị tautos pasakojimą ${ }^{2}$. Lietuvos miestai ir miesteliai, kaip žinia, taip pat istoriškai daugiausia buvo gyvenami kitataučių, lietuvèti pradèjo tik tarpukariu, be to, juos, kaip kažkokią didesnę vertę turinčius urbanistinius darinius, nespecialistams sunku suvokti.

Sakralinis paveldas - įvairių konfesijų šventovès, religinio turinio meno kūriniai, kulto daiktai ar drabužiai ir t. t. - sekuliarizuotos visuomenès sunkiai besuprantamas, ikonografiškai nebeperskaitomas. Savo ruožtu etnokultūrinis, valstietijos palikimas nūdienèje poindustrinëje visuomenėje darosi sunkiai pritaikomas ir nebeaktualus arba „suprekinamas“ ir suvulgarinamas atrinktus jo elementus ịtraukiant ị šiuolaikinę masinę vartoseną („duokim garo“ fenomenas). O mūsų tėvų ir senelių atmintis bei paveldas iš esmès sutampa su sovietmečiu - sudètingu ir dramatišku laikotarpiu, tebekeliančiu didelius visuomenès bei istorikų ginčus dèl jo adekvataus pažinimo ir vertinimo. Galbūt minètos gyvenamosios aplinkos nuvertinimo, negebėjimo ją adekvačiai „perskaityti“ problemos ir būtų šio komplikuoto santykio su mūsų praeitimi pasekmè? Tad kuo remtis, su kuo tapatintis? Gal belieka tik gamtos vertybès, kultūriniai kraštovaizdžiai ir piliakalniai - archeologiniai paminklai, kuriuos dar reikia išmokti adekvačiai „perskaityti“? Kaip įveikti įsisenejjusị visuomenės susvetimèjimą su praeities palikimu, kurị šios srities specialistai vertina ir saugo kaip gamtos ir kultūros turtus bei išteklius? Akivaizdu, kad tam pirmiausia reikia ilgo, nuoseklaus ir sisteminio ugdomojo darbo, kuri būtina pradèti kuo anksčiau, jau nuo ikimokyklinio amžiaus vaikų edukacijos, ypač akcentuojant vidurinio lavinimo tarpsnị, paklojantị pagrindus moksleivio santykiams su kultūra ir gyvenamaja erdve.

Atsižvelgiant ị tai šio tyrimo objektas - paveldo ugdymo principai, siekiniai ir metodai, taikomi formaliajame ir neformaliajame švietime, ypač pasitelkus paveldą mokant istorijos.

Tyrimo tikslas - atskleisti paveldo ugdymo vaikams specifiką ir sunkumus bendrosios paveldošvietos kontekste bei pateikti praktinių jos įgyvendinimo rekomendacijų.

Tyrimo uždaviniai:

- išanalizuoti, kokių kompetencijų ir įgūdžių moksleiviams gali suteikti mokymas, pasitelkus paveldą;

- aptarti šiuolaikinės paveldo edukacijos ir interpretacijos formaliajam ir neformaliajam vaikų ugdymui teikiamas galimybes;

- pristatyti ir išnagrinèti esminius paveldo interpretacijos principus bei pateikti ,gerosios praktikos“ pavyzdžių ir priemonių, naudojamų siekiant užtikrinti sklandų nacionalinės kultūros puoselèjimo, perdavimo darbą jaunesnèms kartoms bei aptarti vaikų vietinio ir išvažiuojamojo turizmo neformaliosios edukacijos, pasitelkus paveldą, ypatumus;

- pateikti rekomendacijų, leidžiančių plètoti sisteminị ir nuoseklų požiūrị i vaikų edukaciją, pasitelkus paveldą.

Darbe taikomi aprašomasis, analitinis-sintetinis metodai.

Didysis istorinis pasakojimas - oficialiai ịtvirtinta ir kolektyvinès atminties atributais (atmintinomis datomis, paminklais, viešaisiais minejjimais ir t. t.) bei masinès komunikacijos priemonemis (istoriografija, vadovèliais, dokumentiniais ir meniniais filmais, istorine publicistika ir t. t.) perteikiama ir palaikoma tautos praeities versija, skirta pagrissti jos nueitą istorijos kelią, užtikrinti istorinį tęstinumą, susiejantị praeities, dabarties ir ateities kartas, formuoti bei palaikyti tam tikrą kolektyvinị tapatumą. 


\section{Ugdymo, pasitelkus paveldą, siekiniai edukacinès psichologijos šviesoje}

Vienas svarbiausių šios temos leidinių užsienyje - metodinė knyga „Paveldas klasëje. Praktinis vadovas mokytojams“, kurioje aptariamas klausimas, kaip būtu galima paveldą pritaikyti mokant istorijos mokykloje ir už jos ribų. Čia pateikti teoriniai modeliai ir praktiniai paveldo integravimo i i istorijos ugdymo procesą pavyzdžiai, kurie galètų padèti mokytojui sékmingai panaudoti paveldą istorijos pamokose (Heritage in the Classroom, 2005). Nors Lietuvos formaluji švietimą reglamentuojančiuose dokumentuose taip pat teigiama, kad paveldą būtina pasitelkti mokant istorijos ir padèti ugdyti mokinių gebejjimą gerbti praeities palikimą, tačiau ši tema išsamiau neplètojama. Todèl, siekdamos užpildyti šią spragą, šio straipsnio autore kartu su dr. Živile Mikailiene parengè metodinę knygą „Pasaulis prasideda čia. Paveldo ugdymo principai mokyklinio amžiaus vaikams“ (Čepaitienè, Mikailienè, 2017). Knygelès parengimą finansavo Lietuvos kultūros taryba, leidybą - Kultūros paveldo departamentas prie LR kultūros ministerijos. Šios metodinès priemonès koncepciją nusako pats jos pavadinimas. „Pasaulis prasideda čia“ - ne tik graži metafora, pirmiausia skatinimas apsidairyti aplinkui, pradèti pažinti paveldą nuo artimiausios aplinkos, kuri atrodo tokia kasdieniška, iprasta, netgi nuobodi ar neįdomi ir anaiptol neprilygstanti tolimųjų kraštų vilionėms, holivudinių filmų perteikiamiems specialiesiems efektams ar pasinėrimui ị saldų šiuolaikinių technologijų kuriamą virtualujį pasaulį. Tuo pagrindu suformuota „koncentrinių ratų“ koncepcija, pagelbstinti paveldo ugdytojams aiškiau suvokti savo prioritetus ir siekinius vaikų edukacijos, pasitelkus paveldą, procese.

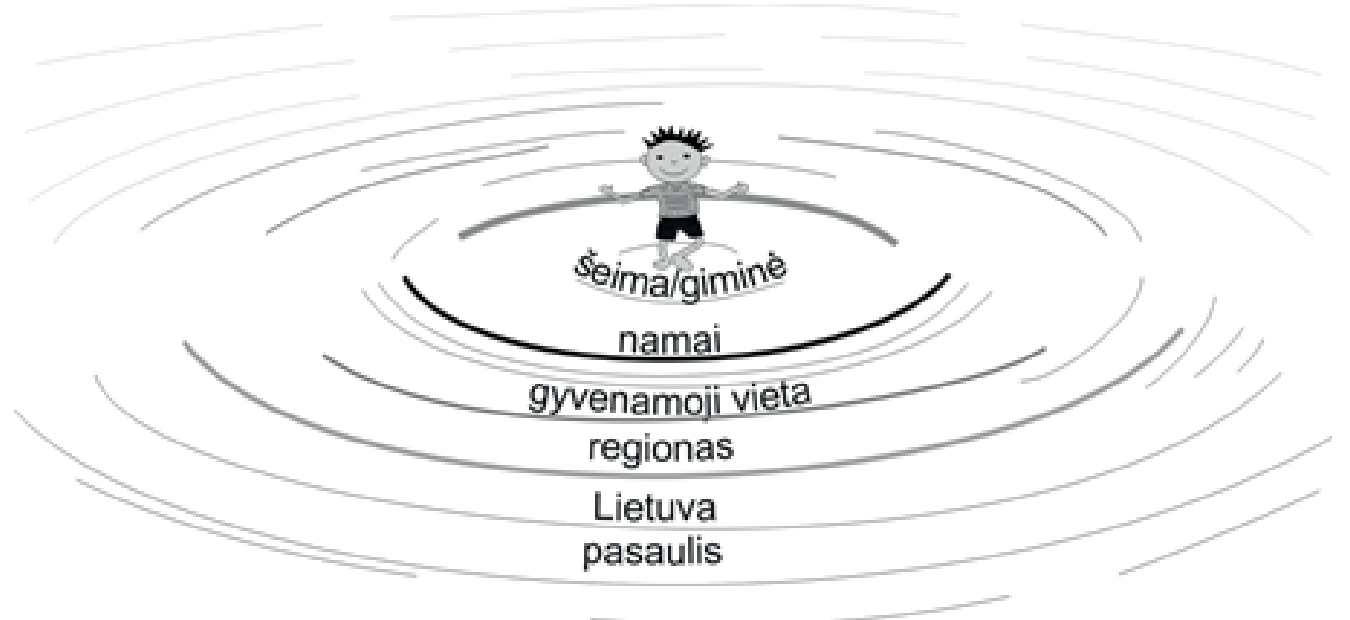

1 pav. Vaikų edukacijos, pasitelkus paveldą, erdvinių prioritetų seka („koncentriniai ratai“)

Šiuo leidiniu siekta dvejopo tikslo: pateikti mokytojams ir tėvams rekomendacijas ir patarimus, paremtus Lietuvos ir kitų šalių neformaliosios paveldo edukacijos gerosios praktikos pavyzdžiais, bei, kas daug svarbiau, paskatinti ugdyti savo krašto, tèviškès, Tẻvynès patriotus, neabejingus jos likimui ir kultūros būklei. Juk nèra ir negali būti šeimos paveldo, atskirto nuo vietos bendruomenès, valstybės, Europos ar pasaulio paveldo, ir atvirkščiai (Howard, 2003: 1). Paveldas - tai ne tik už šią sritị atsakingų valstybės pareigūnų sudaromuose sąrašuose esantys išskirtinès vertès kūriniai, pastatai ar vietovès, bet ir tie daiktai, simboliai, vietos ar ženklai, kuriuos paprasti žmonès, galbūt patys to nesuvokdami ir neįvardindami, laiko brangiais ir svarbiais savo tapatumui. Todèl taip plačiai ir integraliai suvokiamo paveldo pažinimas turi prasidèti nuo mažų dienų - darželio ar pradinių klasių, ir nuo mažų dalykų - artimiausios aplinkos, namų, kuriuose vaikas gyvena, daiktų ir kraštovaizdžio, kurie jị supa, tėviškès, kurioje jis auga ir bręsta, galiausiai Tèvynès, su kuria ji susieja visų iki jo gyvenusių protėvių kartų triūsas ir šioje žemėje palikti net ir patys kukliausi pédsakai. Taigi i paveldą būtina žvelgti integraliai, t. y. siekiant peržengti istoriškai susiklosčiusias dirbtines pertvaras tarp „oficialaus“ ir „neoficialaus“, „gamtos“ ir „kultūros“, „materialiojo“ ir „,nematerialiojo“, valstybès saugomo ir bendruomenių ar šeimos puoselejjamo. Tai reiškia, kad, atsižvelgiant ị konkrečią situaciją, mokytojo pastangas ir į ši vyksmą įtrauktų moksleivių kūrybiškumą bei suinteresuotumą, paveldo ugdymo tikslai ir 
uždaviniai gali būti ịgyvendinami istorijos, geografijos, pilietinio ugdymo, lietuvių kalbos, dailès, darbų, net fizinio lavinimo ir kitose pamokose ar su jomis susijusioje užklasinejje veikloje, tarsi žaidžiant ir pramogaujant, taigi tarsi savaime ir be prievartos ịtraukiant bei aktyvinant visas vaiko jusles, protą ir smalsumą. Šiame procese nemenką vietą užima ir vietinis bei išvažiuojamasis turizmas.

Gali kilti pagrịstas klausimas, kokias kompetencijas ir gebẻjimus galima būtų ugdyti, pasitelkus paveldą, integruojant kultūros ir gamtos vertybes ị istorijos pamokas ir / ar mokinių užklasinę veiklą? Kaip kultūros ir gamtos vertybės gali papildyti bei praturtinti moksleivių istorini suvokimą?

1951 m. edukacinès psichologijos atstovas Benjaminas Bloomas sukūrẻ ugdymo tikslų taksonomijos modelį, kuriuo siekè kuo efektyviau organizuoti ir vykdyti moksleivių švietimo procesą. Remiantis šiuo modeliu, mokymosi procese turi lavėti trys pagrindinès sritys: kognityvinè, afektyvioji ir psichomotorinė. Pirmoji sudaryta iš žemesniųjų gebẻjimų, kuriuos apima gebejjimas įsiminti faktines žinias, jas suvokti bei pritaikyti praktinėje veikloje, ir aukštesniųjų gebẻjimų, tokių kaip gebẻjimas sukauptas žinias analizuoti, sintezuoti bei kritiškai vertinti. Antroji sritis - afektyvioji, susijusi jausmais, emocijomis, moralinėmis vertybèmis, estetine pajauta ir šių gebejjimų vystymu bei pritaikymu realiame gyvenime. Trečia sritis - psichomotorinè, susijusi su savo kūno valdymo ir lavinimo ịgūdžiais, gebejjimu atlikti tam tikrus fizinius darbus ar užsiimti tam tikra fizine veikla (Bloom, Engelhart, Furst, Hill, Krathwohl, 1956). Iš esmės paveldas, kaip ugdymo priemoné, gali lavinti visas tris B. Bloomo taksonomijoje apibrěžtas sritis. Žvelgiant per kognityvinių gebejjimu prizmę, istorijos užduotys, integruojančios materialų kilnojamajị, nekilnojamajį ir nematerialų paveldą, gali ugdyti mokinių gebẻjimą atpažinti ir tirti ịvairių formų istorinę informaciją, gaunamą regos, klausos, skonio, lytejjimo pojūčiais, ir apibūdinti ją raštu, vaizdo / garso priemonėmis, taip pat mokantis perteikti, kokių naujų žinių sukaupė ją tiriant. Aukštesniujų gebėjimų aspektu paveldo pritaikymas mokant istorijos gali padèti ugdyti gebẻjimą kritiškai vertinti tiek pati informacijos rinkimo procesą, tiek iš konkrečiu informacijos šaltinių surinktą medžiagą, ją sèkmingai analizuoti ir sintetinti, tinkamai struktūruoti ir perteikti. Galiausiai ugdomas gebejjimas racionaliai diskutuoti ir argumentuoti, remiantis surinkta bei apdorota informacija. Žvelgiant per afektyviosios srities prizmę, istorijos ugdymas, integruodamas paveldą, ypač jei jis susijęs su įvairiomis meno formomis (daile, architektūra, literatūra, poezija, muzika, šokiu ir t. t.), gali prisidèti prie emocinių, empatinių ir estetinių asmenybės gebėjimų arba vadinamojo emocinio intelekto lavinimo. Kaip žinia, kultūros vertybių „liūto dalị“" sudaro ịvairių rūšių meno kūriniai, sukurti talentingų menininkų ir pasižymintys aukšta atlikimo kokybe, todèl čia atsiveria labai plati paveldo vertybių panaudojimo formaliajame bei neformaliajame švietime perspektyva. Tuo tarpu kalbant apie psichomotorinių gebejjimų ugdymą, paveldas, jei tik jị leidžiama ne tik pamatyti ir teoriškai apmąstyti, bet ir išbandyti, pajusti, patirti fiziškai arba panaudoti praktiškai, gali labai prisidèti prie asmens psichofiziologinès raidos. Tam ypač pasitarnauja gamtos paveldo vertybių ar kultūrinių kraštovaizdžių tyrinèjimai (Ham, 1992). Pastebėtina, kad trumpesnès ar ilgesnès kelionès, iškylos, žygiai ir turistinès išvykos visas minètas gebejjimų sritis gali sẻkmingai lavinti kartu.

\section{Paveldo verčių ir prasmių perteikimo formos}

Šiandien pripažįstama, kad teise i pavelda yra viena iš pamatinių žmogaus kultūrinių teisių. Geriausiai ją galima užtikrinti skatinant megzti dialogą tarp paveldo vertybèmis besirūpinančių valstybès pareigūnų ar istorijos pažinimo entuziastų ir likusios, į šią veiklą nepakankamai ar visai neįtrauktos visuomenès, nes valstybė pati viena finansiškai ir administraciniu požiūriu nepajègi užtikrinti tinkamos paveldo apsaugos. Todèl šiuolaikinė paveldosauga, siekdama stiprinti vietos demokratiją ir igalinti visuomenę, deklaruoja darnios ir atsakingos visuomenès ugdymo, gamtą tausojančios ir kultūrą puoselëjančios veiklos svarbą (Harrison, 2013: 204-223). Tačiau kaip praktiškai pasiekti, kad kuo daugiau visuomenès narių sąmoningai įsitrauktų i paveldosaugos ir aplinkosaugos procesus? Čia gali padèti šiuolaikinės paveldošvietos siekiniai, priemonės ir metodai.

Ši sritis apima tokias tarpusavyje susijusias veiklas, kaip:

- pateiktis, arba prezentacija, t. y. prieigos prie paveldo vertybių suteikimas lankytojams, kas iš esmès reiškia paveldo objektų populiarinimą masinèse informavimo priemonėse ir socialiniuose tinkluose (paveldo komunikacija) ir kruopštų jų verčių perteikimo planavimą vietoje, pasiekiamą suteikiant 
fizinę bei informacinę prieiga prie paveldo vertybių, t. y. įrengiant kelio nuorodas, takus, privažiavimus, laužavietes, tualetus, viešojo maitinimo ịstaigas, suvenyrų parduotuvėles ir pan., taip pat renkant, sisteminant ir skleidžiant apie jas sukauptą informaciją. Trumpai tariant, sukuriant ir parengiant visą interpretacijai būtiną infrastruktūrą, įskaitant turistams skirtus stendus, žemėlapius, atlasus, interneto tinklalapius, ekspozicijų schemas ir t. t.;

- gamtos ir kultūros vertybių reikšmių ir verčių perteikimas arba interpretacija - esminių žinių apie lankomą objektą lankytojams suteikimas, jo prasmès atskleidimas. Taigi, jeigu interpretacija apima pasakojimo apie paveldo vietą turini, pateiktis veikiau būtų jos raiškos forma ${ }^{3}$;

- ugdymas pasitelkus pavelda - pasitelkus kultūros ir gamtos vertybes diegiamos tam tikros socialiai bei kultūriškai reikšmingos žinios, socialinès normos ir nuostatos, ugdomi gebẻjimai bei igūdžiai.

Visos kartu šios veiklos sudaro komunikavimo ir ugdymo, pasitelkus paveldą, procesą. Archeologas Timas Kouplendas skyre tris jo lygmenis. Pirmasis, pats žemiausias, yra mokymas apie paveldą. Tai edukacija, kai tiesiog supažindinama su gamtos ar kultūros vertybe ir jos aplinka, nesigilinant ị apsaugos bei kitas problemas. Antrasis lygmuo apibrěžiamas jau kaip mokymas pasitelkus paveldą. Šiuo metu gamtos ar kultūros vertybès tampa tarpdisciplininio mokymo tarpininkès. Taip, pasitelkus paveldą, mokoma kitų pažinimo sričių, pavyzdžiui, istorijos, matematikos, geografijos, kalbų ir t. t. Svarbu atminti, kad mokymas pasitelkus paveldq apima ir mokymą apie pavelda. Trečiasis, aukščiausias, lygmuo yra mokymas, pasitarnaujantis paveldui (Copeland, 2009). Taip tikimasi lankytojus ịtraukti ị paveldosaugos darbą, supažindinti su priimamais šios srities ekspertų sprendimais, mokyti pažinti ir vertinti paveldo objektus, laikyti juos savais. Akivaizdu, kad visais trimis lygmenimis pagrindinị vaidmenị atlieka paveldo vietos ar objekto interpretacija.

\section{Formaliojo ir neformaliojo ugdymo, pasitelkus paveldą, ypatumai}

Iš esmès interpretacija yra formaliojo ir neformaliojo ugdymo, pasitelkus paveldą, pamatas. Nors formalusis ugdymas buvo žinomas ir taikomas nuo seniausių laikų (Prentice, 1995: 146-169), šiandien ugdymo, pasitelkus paveldą, procese taikomi tiek formaliojo, tiek ir neformaliojo mokymo metodai. Tradicinè samprata „aklas - i mokyklą, kurčias - ị muziejų“ (Allard, 2000: 125) - vis labiau kvestionuojama. Didinant interpretacijos efektyvumą ir patrauklumą, dažniau pasitelkiami neformaliojo ugdymo metodai arba vieni derinami su kitais. Paveldo vietų ar muziejinèse interpretacijose jau siekiama pasitelkti kuo daugiau lankytojų juslių ir gebejjimų - klausymą, rašymą, skaitymą, piešimą, modeliavimą, dainavimą, vaidybą, šokị ir t. t. Tai susiję su siekiu skatinti lankytojų, ypač vaikų, smalsumą, kūrybiškumą, kritinị santykị su praeitimi. Lankytojas turi galimybę aktyviai reaguoti ị paveldo vietą ar objektą, o ne vien pasyviai išklausyti gido ar mokytojo pateikiamą informaciją (Beck, Cable, 1998).

Neformalusis ugdymas dažniausia pasitelkiamas laisvalaikiu ir neformalioje aplinkoje - iškylose, ekskursijoje, žygiuose (Light, 1995: 117-145). Jis yra savanoriškas ir sąmoningas, tad ir dalyviai daug labiau motyvuoti, jų kognityviniai bei emociniai gebejjimai daug labiau įtraukiami ị paveldo pažinimo procesus, todèl gaunama informacija ir patiriami ịspūdžiai geriau ịsisąmoninami, adekvačiau suprantami bei ịsimenami. Jau pats vietos ar pastato mastelis, dydis, objektų išsidėstymas erdvėje, jų struktūriniai, funkciniai, stilistiniai, estetiniai bruožai tampa ne tik žodinès, bet ir neverbalinès, psichomotorinės informacijos, kurią kitaip būtų sunku apčiuopti ir suvokti, šaltiniu. Be to, remiantis neformaliojo ugdymo principais, naują informaciją klausytojas įsisąmonina ne tik stebėdamas ir klausydamas, bet kartais ir pats įsitraukdamas ị inscenizuojamus veiksmus (senovès valgių gamybą ir ragavimą, monetų kalimą, viduramžių mūšių rekonstrukcijas ir pan.). Žaidimas, nuotykio potyris, juokas - tai vis vadinamuoju edutainment (iš angliškų žodžių education „mokymas“ ir entertainment - „pramoga“) pasiekiamas geresnio praeities pažinimo efektas. Kūrybiškumas gali reikštis įvairiai, kad ir spontaniškai į interpretacijos procesą įtraukiant aplinkos objektus. Pavyzdžiui,

\footnotetext{
Esama ir kitų šių sąvokų aiškinimų. Antai interpretacija nebūtinai turi būti viešai pristatyta, ją galima tiesiog iš anksto žinoti kaip tam tikrą vietos istorijos versiją. Šiuo atveju pateiktis - tai interpretacijos pateikimas auditorijai stenduose, gido pasakojimu ir pan. Anglakalbejje literatūroje prezentacija ir interpretacija dažnai pavartojamos ir sinonimiškai.
} 
pažintinio pasivaikščiojimo po pirmajį Vilniaus „miegamajji rajoną“ - Žirmūnus metu gidè sumaniai išnaudoja stotelèje kabančią viešojo transporto schemą, kurią patogu pasitelkti ekskursijos dalyviams aiškinant miesto plètros sovietmečiu etapus ir naujujų mikrorajonų statybos eigą.

\section{Paveldo interpretacijos reikšmè organizuojant moksleivių turizmą}

Interpretaciją paprasčiausia apibrěžti kaip „meną paaiškinti vietovės reikšmę jos lankytojams, pabrěžiant jos išsaugojimo poreikị“" (Aldridge, 1989: 64). Kada tiksliai prasidèjo paveldo, tai yra praeities reliktų, interpretavimas, vargu ar beįmanoma nustatyti. İdomu, kad, nepaisant tūkstantmetės pasakojimų tradicijos, sukaupta žinių apie paveldo vertybes perteikimo patirtis pirmą kartą išsamiau apmąstyta ir aprašyta neseniai - tik $1957 \mathrm{~m}$. Tai padarė JAV Nacionalinių parkų tarnybos darbuotojas Frymenas Tildenas, sukūręs savitą paveldo perteikimo metodiką ir teoriją, vèliau išaugusią ị savarankišką šios srities filosofiją. Nedidelès apimties knygelèje „Mūsų paveldo interpretacija“, kuri padare didžiulę įtaką tolesnei paveldo interpretavimo raidai, remdamasis ilgamečiu savo ir kitų paveldo interpretatorių i̇dirbiu, F. Tildenas išskyre ir aprašė efektyvios interpretacijos principus, kuriuos, beje, talentingas gidas dažnai atranda ir taiko intuityviai, apie juos net nenutuokdamas. Ši knygelè iki šiol yra nepralenkiamas paveldo komunikacijos vadovas, kuri pateikiamos priemonès, kaip turi būti kuriamas ir perteikiamas pasakojimas apie paveldo vietą ar objektą, kad lankytojai jị teisingai suprastų ir būtų ịkvèpti jị saugoti.

Interpretacija F. Tildenui iš esmès reiške „edukacinę veiklą, kuria siekiama atskleisti prasmes ir ryšius, pasitelkus originalius objektus, tiesioginę patirtị ir iliustruojančias informacijos priemones“" (Tilden, 1977: 8). Jo teeigimu, pagrindinis paveldo interpretavimo tikslas - ,interpretuojant suprasti, supratus įvertinti, ịvertinus saugoti““ (Tilden, 1977: 38). Tai reiškia, kad pasakojimu ir jame užkoduota socialine žinia (pranešimu) siekiama ne tik suteikti informacijos apie lankomo objekto istoriją, bet ir provokuoti, skatinti paveldo objekto lankytojo ar turistų būrio elgesio pokyčius. Tam, kad būtų pasiektas šis galutinis kultūros vertybių išsaugojimo tikslas suformuluoti šeši pavyzdžiais iliustruoti principai, kuriais turètų remtis gera paveldo interpretacija. Tiesa, leidinyje autorius nurodè ir daug kitų iki šiol aktualių sudedamujų interpretacijos dalių, kurių neišskyrè kaip atskiru principų, tarp kurių paminèjo ir vieną neįkainojamą „,ingredientą““ - interpretatoriaus meilę atliekamam darbui, jo paties asmenybės jègą ir entuziazmą, gebantị patraukti ir ịkvèpti lankytojus.

Pirmasis jų atkreipia dėmesị i tai, kad lankytojui pirmiausia ir labiausia rūpi tai, kas paveldo vertybejje ar pasakojime apie ją tiesiogiai ir netiesiogiai siejasi su jo paties asmeniu, patirtimi, nuostatomis bei turimomis žiniomis. Iš esmès lankytojai visur, net užsienio kelionėse, nesąmoningai pirmiausia ieško savo paveldo, pavyzdžiui, Paryžiuje, Lotynų kvartale, esančioje Šv. Severino bažnyčioje turistas iš Lietuvos apsidžiaugs atpažinęs Aušros vartų Švč. Mergelès Marijos atvaizdo kopiją. Tad, nors gidas nepajègus tiesiogiai kreiptis i kiekvieną ekskursijos dalyvị ar juolab žinoti jo interesų, bet jis gali apeliuoti ị jų turimas žinias apie praeitį ir (numanomą) bendrą patirtį. Paveikus būdas yra lankytojo skatinimas susimąstyti, koks bütų buvęs jo gyvenimas, jei jis bütu gyvenęs aptariamuoju metu, ka jis būtu daręs tomis aplinkybèmis ir tose situacijose, kuriose gyveno pasakojamos istorijos veikèjai, kokie moraliniai pasirinkimai tada bütų buvę svarbūs, ka jie jam būtu reiškę? Beje, vaikų auditorijai paveikiausia tapatintis su praeityje gyvenusiais bendraamžiais.

Antrasis principas nurodo sudètingus informavimo ir prasmès kūrimo ryšius interpretacijoje. Kalbant apie tai reikia atsižvelgti ị seniai žinomą tiesą, kad lankytojo, ypač vaiko, „užvertimas“ sausais faktais, datomis, pavardèmis ir negirdètais specifiniais terminais gali sukelti priešišką reakciją ar net ilgam atgrasyti nuo noro toliau domètis istorija bei paveldu. Tad, nors daugeliu atvejų, siekiant geriau suprasti lankomą vietą ir jos reikšmę, tam tikrų, nors ir ribotų, žinių apie ją suteikimas neišvengiamas, tačiau, be minèto tiesioginio susiejimo su lankytojo protu, žiniomis ir jausmais, tai bus mažai efektyvu ir ši informacija jo galvoje ilgam neužsilaikys. Geriausiai pavyksta lankytoją sudominti susiejant lankomo objekto ar vietos istoriją su bendresne krašto, šalies ar Europos istorija, kad labiau išryškètų aptariamo reiškinio svarba, unikalumas arba - priešingai, tipiškumas, jo reikšmė valstybès, regiono, žemyno socialiniuose ar kultūros procesuose. Pavyzdžiui, kalbant apie Rietavą, kuriame 1892 m. pirmąkart Lietuvoje užžiebta elektra, ši faktą tinka susieti su bendra elektros atradimo, naudojimo, elektrifikacijos tinklų kūrimo istorija. Ši prieiga lemia ir penktą principą - sėkmingas ir paveikus pasakojimas remiasi visuminiu vaizdu. 
Trečiasis principas susijęs su klausimu, gera interpretacija yra menas ar mokslas? Praktika rodo, kad dažnai tenka pasitelkti mokslines žinias ar metodus, juos pateikiant sumaniai, kūrybiškai, siekiant pažadinti lankytojo nespecialisto, juolab vaiko susidomėjimą, kartu skatinant jo istorinę vaizduotę. Tačiau aiškiai, sklandžiai, nuosekliai ir įdomiai papasakota, įkvepianti istorija pati savaime yra menas, čia būtina puiki pasakotojo iškalba, artistiniai gebejjimai, lankstumas ir ịgūdis, atsižvelgiant ị auditoriją, parinkti kalbos stilių, noras užmegzti šiltą emocinị ryši su ja, tam dažnai padeda ir gebèjimas laiku bei vietoje pajuokauti (žinoma, jei tik lankoma vieta ir jos istorija tai leidžia, kas, savaime aišku, būtų nepriimtina tragiškų ịvykių vietose.... $)^{4}$. Tačiau būtina palikti vietos ir lankytojų vaizduotei (Craig, 1989: 107-112).

Savo ruožtu svarbus ketvirtasis principas atkreipia dėmesị ị giluminị interpretacijos tikslą - ne mokyti, tiksliau, ne tik mokyti, instruktuoti ir suteikti žinių, bet veikiau provokuoti, pačius lankytojus skatinti mąstyti ir tų žinių vẻliau savarankiškai siekti, patiems daryti išvadas ir taip patirti atradimo džiaugsmą, kuris yra bene ịsimintiniausias ir ilgiausiai išliekantis geros paveldo interpretacijos efektas. Pavyzdžiui, muziejaus salèje, kur vaizduojama vieno Belgijos miesto XIX a. mokyklos klasė, lankytojai moksleiviai gido paprašyti surasti daiktus, kurių tais laikais ten negalëjo büti. Taip vaikai galèjo „diskvalifikuoti“ ant suolo gulintị diską ar skaičiuotuvą. Kartu gidas turi dingstị pakalbèti apie technologijų kaitą ir išradimų sukūrimo laiką, taip ugdydamas istoriškumo jausma. Kita vertus, provokavimas gali sutelkti greitai slopstantị vaikų dėmesị, lavinti jų pastabumą ir loginį mąstymą. Antai Maskvos priemiestyje esančio Carycino muziejaus-draustinio ekspozicijoje kabo Rusijos imperatoriaus šeimos vaikų piešiniai. Gidè moksleivių grupės prašo atspèti, kuriuos iš jų piešè mergaitès, o kuriuos - berniukai. Vaikai užduotị atlieka iškart ir be klaidų: caraičiai, pasirodo, išties labiau mėgo karinę tematiką, o caraitès - žmonių portretus ir augalus. Tai rodytų, kad geroje interpretacijoje būtina atsižvelgti ir ị lyties aspektą bei su tuo susijusius psichologinius ypatumus (Holcomb, 1998: 37-55). Esama ir kitų provokavimo būdų. Štai kai kuriose „gyvosiose“ interpretacijose epochos kostiumu apsirengęs ar net konkretų istorinị veikèją vaidinantis gidas pasakoja istoriją ,iš savo varpinès“, kuri gali visiškai nesutapti su kitam socialiniam sluoksniui, tautai, rasei ar lyčiai atstovaujančio personažo pateikiama tų pačių ịvykių versija ir vertinimais, tad lankytojas verčiamas susimąstyti apie istorinio objektyvumo ribas. Pavyzdžiui, Kanadoje, Midlando vietovèje prie Ontarijo, atkurta XVIII a. čia stovėjusi prancūzų misionierių jèzuitų gyvenvieté $\dot{e}^{5}$, kurioje gidais dirba ir baltieji, ịsikūniję i jèzuitų vaidmenị, ir vietos gyventojai indènai huronai. İdomu, kad kiekviena iš šių grupių perteikia katalikiškos misijos istoriją iš savos perspektyvos, o jos anaiptol nesutampa, tai lankytojams atskleidžia praeityje buvusius ir nūnai iškylančius atvirus ar paslèptus, suderinamus ar konfliktuojančius skirtingų kultūrinių bendrijų interesus... Savo ruožtu saugomose gamtos vietovėse lankytojai skatinami atkreipti dèmesị i aktualias gamtosaugos problemas. Antai UNESCO Pasaulio paveldo vietovejje Kuršiu nerijoje turistai raginami savo darytas kopų nuotraukas siųsti šio Nacionalinio parko darbuotojams, taip ịsitraukiant ị kopų kaitos stebėseną bei ugdant jų atsakomybę už ši unikalų ir trapų Lietuvos kraštovaizdžio kampelį. Taigi gera interpretacija visada turi būti lydima subtiliai perduodamo poreikio išsaugoti paveldo vietovę.

Kaip minèta, penktasis principas teigia, kad iš pasakojimo lankytojas turètų susidaryti visuminį vaizdą apie vietą ar reiškinị, kokios ịdomios ar iškalbingos bebūtų konkrečios detalès ar šalutinès pasakojimo gijos. Bet tai anaiptol nereiškia, kad reikia pasakoti absoliučiai viską. Interpretatorius turi būti entuziastingas ir užsidegęs, bet ne per daug, kad, nugrimzdęs ị savo pasakojimą ir pamiršęs apie lekiančias valandas, neprarastų ryšio su išvargusiais ar jau nuobodžiaujančiais klausytojais. Optimali ekskursija turètų tęstis ne ilgiau kaip pusantros ar dvi valandas, jaunesnio amžiaus vaikams - iki valandos, todėl pasakojant ir kažką rodant būtina nepastebimai „vertinti“ klausytojų nuotaikas, jų energijos ir susidomejjimo lygị. Be to, planuojant pažintini pasivaikščiojimą būtina iš anksto numatyti maršrutą, kuriuo bus vedama grupè, ir atstumą, kurị teks nueiti (praverstų ir išankstinis įspejimas apsiauti patogią avalynę bei tinkamai apsirengti), kad jo dalyviai fiziškai nepervargtų ar nesušaltų / neperkaistų, nes tai, be abejo, nepageidautinai sumažintų edukacijos, pasitelkus

Visgi smurto ir tragedijos ryšys su humoru lieka ambivalentiškas. Kartais juokas belieka vienintelis silpnujų ginklas prieš padèties absurdą ir situacijos beviltiškumą, prisiminkime Balio Sruogos romaną „Dievų miškas“.

5 Žr. oficialų "Sainte Marie among the Hurons” paveldo vietovès tinklalapị: http://www.saintemarieamongthehurons.on.ca/sm/en/ Home/index.htm. 
paveldą, efektyvumą. Reikètų atsižvelgti ir ị būsimo maršruto ypatumus (ịkalnè, nelygus reljefas, pelkètos vietos, miškas, triukšminga miesto gatvè ir t. t.), lankomų vietų specifiką. Kaip žinia, sakraliniuose objektuose būtina laikytis pagarbios tylos, atitikti tam tikrą aprangos kodą ir t. t.

Galiausiai paskutinis, šeštasis principas skelbia iš pirmo žvilgsnio lyg ir akivaizdžią tiesą, kad vaikai pasakojimą suvokia kitaip nei suaugusieji, taigi derètų prie jų prisitaikyti. Bet kaip? Vaikai pastebi ir ịsimena detales ar žodžius, ị kuriuos suaugę paprastai nekreiptų dėmesio. Sudètingos ir daugiabriaunès istorinès temos, sunkūs ar nežinomi tarptautiniai žodžiai dažnai bemat išsklaido jų dėmesị ir įvaro nuobodulį. Ir priešingai - vaikams patinka aukščiausiojo laipsnio būdvardžiai (,didžiausias“, „,rečiausias“, „,mažiausias“, „,keisčiausias“...), kaip ir patys jais apibūdinami daiktai ar pastatai, kuriuos smagu paliesti ar ị juos įeiti / užlipti. Taip pat visada reikia atminti, kad vaikams nepatinka likti vien pasyviais klausytojais, jie labai mėgta ịsitraukti ị veiksmą - išbandyti, liesti, uostyti ir net ragauti, kas rimtuose muziejuose dažniausia, deja, draudžiama...

Paaugliai paprastai laikomi „pačiais sunkiausiais“ paveldo vietų lankytojais, tačiau net ir juos įmanoma sudominti tinkamai parinkta interpretacija, kuri apeliuoja ị jų specifinius interesus ir jausmus, nevengia sąžiningai ir tiesiai kalbèti aštresnėmis bei skaudesnėmis temomis. Pavyzdžiui, paauglystẻje dažnai iškylančios egzistencijos prasmès, mirties ir pomirtinio gyvenimo, gebėjimo susidoroti su užgriuvusiais psichologiniais sunkumais ir panašios temos gali būti aptariamos smurtinio paveldo vietose (istorinių mūšių laukuose, buvusiuose konclageriuose ar kalejimuose, holokausto vietose, atkurtuose partizanų bunkeriuose ir pan.) (Ashworth, Hartmann 2009: 245-260; Grappin, Jurion de Waha 2007: 169-174). Šiuo atveju ypač padètu gyvas bendravimas su šių dramatiškų ịvykių liudininkais, kurie turi asmeninès karo, pokario žiaurumo, tremties, kolektyvizacijos patirties.

\section{Paveldo interpretacijos plètra ir kritika}

Vèlesni interpretacijos teoretikai pabrèžè, kad ji yra mokslinès, faktinès ir kitos informacijos apie objektą, kurios paprasti žmonès - nespecialistai galètų nesuprasti, ,išvertimas“ $i$ jiems suprantamą kalbą ir smagus, ịdomus pateikimas (Ham, 1992). Taip pradèta labiau pabrezžti ne ugdymą, ko sieké F. Tildenas, bet komunikaciją - informacijos, emocijų, vertybių perdavimą ir pramogą. Šiuo atveju didžiausias dèmesys kreipiamas ị tai, kaip perduodama žinia (pagrindinis interpretacijos pranešimas), ir daroma prielaida, kad, jei tai padaryta tinkamai, to savaime pakaks, kad auditorija objektą pažintų.

Šiandien dažnai pabréžiama, kad tinkamą interpretaciją turi sudaryti keturi pagrindiniai elementai:

1. ji turi teikti malonumą;

2. turi būti aktuali;

3. gerai parengta;

4. turi turèti aiškią temą, nes kelių temų maišymas ar „šokinèjimas“ nuo vienos prie kitos lankytojus gali gluminti ar net atstumti (Ham, 1992: 9).

Atsižvelgiant ị tai, interpretuojamas objektas atstovauja oficialiam ar neoficialiam paveldo tipui, interpretacijos adresantai gali būti tiek ekspertai (atitinkamų akademinių disciplinų atstovai ar paveldosaugos pareigūnai), tiek pelno siekiančios verslo struktūros, tiek ir vietinės bendruomenès, išnaudojančios paveldą socialiniam veikimui (pavyzdžiui, suburti savo narius, stiprinti vietos tapatumą), arba menininkai bei amatininkai, pasitelkiantys (ne)materialaus paveldo praktikas ir tradicijas savo performansuose. Akivaizdu, kad dèl kartais išties skirtingų interesų šios grupés gali pateikti alternatyvias arba net tarpusavyje konfliktuojančias tų pačių objektų, vietovių ar tradicijų interpretacijas. Kita vertus, neoficialaus paveldo formos gali virsti oficialiomis, palaikomomis net valstybès lygmeniu, kaip atsitiko su Joninių šventimu.

Taigi, kaip matėme, šiandien ypač svarbus tampa interpretacijos kürejjo-adresanto ir jos recipiento-adresato ryšys. Jeigu anksčiau tikèta, kad vietovès lankytojas veikiau pasyviai priima ir ịsisąmonina jam interpretatoriaus perteikiamą informaciją, tai atlikus sociologinius tyrimus paaiškejo, kad taip manyti buvo klaida, todèl imta labiau atsižvelgti ị pačių lankytojų lūkesčius ir poreikius (Beck, Cable, 1998). 
Vienakryptė ir vienapusès specialisto atrinktos informacijos pateikimas ,iš viršaus“ vadintinas pozityvistiniu interpretacijos metodu (Howard, 2003: 251-254). Tokios interpretacijos trūkumas susijęs su dažnai pamirštamu faktu, kad ji, ypač komunikuojama gyvų žmonių, nėra autentiškas ir tikslus praeities perteikimas. Kai kurie specialistai apgailestauja, kad, nepaisant išaugusio interpretacijos populiarumo ir ištobulintų metodų, neretai ji neišvengia istorijos banalinimo, reakcingų, paviršutiniškų ar saldžiai romantizuotų požiūrių piršimo lankytojams, atviro paveldo sukomercinimo, kai ekskursijoje maloniai nuteikti įdomaus bei smagaus gido pasakojimo turistai primygtinai paraginami apsipirkti muziejaus ar paveldo vietos parduotuvejje... Kritikų nuomone, pagrindinè turizmo industrijos veikiamos interpretacijos problema yra ta, kad šiandien svarbesnè tampa istorinès žinios perteikimo forma, dažnai siejama su pramoga, o ne pati perteikiama informacija, kuri jau nebekelia lankytojui intelektinių ir moralinių iššūkių. Todèl auditorijai ji nebesukelia didesnių emocijų ir apskritai empatijos praeities žmonių gyvenimo sąlygoms ar moraliniams pasirinkimams, noro tą praeitị visapusiškiau pažinti, todèl mažai veikia jų pažiūrų formavimąsi ir kaitą. Tad jų laikysena paveldo atžvilgiu ir toliau lieka pasyvi. Todèl F. Tildeno propaguota ideja ,interpretuojant suprasti, supratus ịvertinti, įvertinus saugoti“ ne visada ịgyvendinama, o trokštami lankytojų elgesio pokyčiai anaiptol neužtikrinti (Uzzell, 1998: 11).

Tačiau esama ir šiuo atžvilgiu optimistiškiau nusiteikusių specialistų, teigiančių, kad ,interpretacija, kuri lankytojus provokuoja apie objektą galvoti teigiamai, gali padaryti tą objektą jiems rūpimu. O jei objektai mums rūpi, tikètina, kad mes veiksime jų labui, jei pasitaikys galimybè tai padaryti“" (Silberman, 2013: 22). Taigi gera interpretacija ir toliau turètų stiprinti istoriškumo jausma (reiškinių, technologijų, gyvenimo būdo kismo suvokimo) ir vietos tapatuma. Tad gero ,interpretatoriaus uždavinys - padèti lankytojams atrasti ir geriau suprasti praeitị, vietą, visuomenę ir galiausiai save" (Silberman, 2013: 18). Todèl reikia leisti lankytojams patiems interpretuoti kai kuriuos paveldo objektus, žinoma, prieš tai suteikus visą tam būtiną ,informacinę žaliavą" (faktus, vaizdinę medžiagą, galimybę patiems užsiimti atkuriamąja veikla ir t. t.). Toks interpretacijos metodas vadinamas konstruktyvistiniu.

$2008 \mathrm{~m}$. Tarptautinès paminklų ir vietovių tarybos (ICOMOS) Belgijoje, Enamo mieste, priimtoje chartijoje suformuluotuose 7 pagrindiniuose interpretacijos principuose atsiskleidžia nemažai šiuolaikinès interpretacijos socialinių ir ekonominių aspektų, kurie yra svarbūs Europos Sajungos politikai. Štai šie principai:

1. prieiga ir supratimas;

2. informacijos šaltiniai;

3. dèmesys konkrečiai aplinkai ir kontekstui;

4. autentiškumo išsaugojimas;

5. tvaraus proceso planavimas;

6. socialinès įtraukties siekis;

7. tyrimų, mokymo ir vertinimo reikšmė (Ename charter, 2008).

Iš esmės interpretacija, paremta Enamo chartijos propaguojamais principais, turètų padèti ịveikti sunkumus, kurių ES šalyse šiandien kyla dèl tokių prieštaringų reiškinių kaip multikultūriškumas, daugiakalbystė, imigrantų antplūdžio nulemta sudètinga sociokultūrinè situacija, ,politkorektiškas“ siekis išvengti nelygybės ir diskriminacijos problemų, palaikyti darnią aplinkos raidą, išsaugoti kultūros vertybių autentiškumą. Enamo chartija siekia mažinti išskirtinị profesionalaus interpretatoriaus vaidmenị ir pakeisti jị visų suinteresuotu grupių bendradarbiavimu kuriant interpretaciją. Žinoma, siekis išgirsti visus atrodytų puikus, tačiau tai gali iškelti naujų problemų. Gali būti sudètinga paskatinti visų susijusių grupių narius prisidèti prie paveldosauginès veiklos. Be to, visos grupès turès savų siekių ir vargu ar galès išlikti objektyvios, nes norès kitoms primesti savą interpretacijos versiją. Kai kurios grupės gali net siekti cenzūruoti tam tikrą jos turinį, keliantị joms neigiamų asociacijų. Taigi šis teorinis interpretacijos modelis gali ir nepadèti spręsti praktinių su paveldu susijusių problemų ar konfliktų, jau nekalbant apie tai, kad interpretacijos planavimo ir vykdymo procesas tampa daug sudètingesnis ir sunkiau kontroliuojamas.

Enamo chartija labiausiai pabrèžia tai, kad mes gyvename pakitusioje sociokultūrinèje terpèje, kurioje senaja teorija paremta interpretacija nebegali tinkamai atliepti ir perteikti nūdienio prieštaringo paveldo perteikiamo turinio. Taigi kyla problema, kad interpretatorius, net ir siekdamas išlikti visiškai objektyvus (o toks 
jis būna toli gražu ne visada), „iš viršaus“ perteikdamas savo sukurtą interpretacijos versiją, kuri pasyviai lieka auditorijai, negali atskleisti visų vietovès, pastato, artefakto ar tradicijos verčių bei socialinių reikšmių. Pavyzdžiui, atsižvelgiant ị turistų grupès tautybę, Vilniaus miesto istoriją gidai dažniausia pasakoja pasitelkę konkretų tautinį ar konfesinị kontekstą - lietuvišką, lenkišką, baltarusišką, rusišką, žydišką, katalikišką, protestantišką, stačiatikišką ir kt., taip ignoruodami visus kitus, o tai skatina ne geresnị skirtingų tautų pažinimą ir supratimą, bet įtvirtina įsisenejjusius stereotipus ir tautines nuoskaudas. Kita vertus, kadangi paveldo vietos ir objektai dažnai tampa įvairių bendruomenių, regionų, vietovių, diasporų ar net valstybių ginčų objektu, tai specialisto perteikiama unifikuota interpretacija ir negalètų visiems įtikti. Taigi svarbūs tampa abu komunikacijos akto dalyviai - ir interpretatorius, ir paveldo vietos klausytojai bei jų turima išankstine vietos interpretacija, t. y. jau turimas vaizdinys, susidarytas iš žiniasklaidos, artimujų ar bičiulių pasakojimų apie tą vietą ar objektą. Tad tinkamai organizuotos ekskursijos metu, geranoriškai bendraujant ir gidas, ir jo klausytojai skatinami bandyti aktyviai „kamšyti“ savas praeities pažinimo spragas. Skirtingų interesų grupių diskusija ir bendradarbiavimas gali tapti pagrindine geros interpretacijos varomaja jèga. Todèl nūnai interpretacija yra veikiau procesas, o ne produktas, suinteresuotų šia veikla pusių bendradarbiavimas, ne tik eksperto pristatymas.

\section{Išvados ir rekomendacijos}

Šiandien paveldosauga gali ir turi būti suvokiama ne kaip siaurai ekspertinė biurokratinè sritis, o veikiau kaip reikšminga kultūrinės ir visuomeninès veiklos dalis. Ji ne mažiau nei ị daiktus turi orientuotis ị žmones, vietos bendruomenes, labiausiai pabrěžiant ateities paveldo saugotojų ugdymo būtinybę. Tačiau Lietuvoje ne tik vaikų, bet ir suaugusiụjų edukacija, pasitelkiant paveldą, iki šiol nuosekliau neplètota, todèl būtina ją integruoti į formaliojo ir neformaliojo švietimo sritị, aktyviau remtis „geraisiais“ kitų šalių pavyzdžiais bei patirtimi.

Vykdant moksleivių edukaciją formaliuoju ar neformaliuoju būdu, pasitelkus kultūros paveldą, turètų būti siekiama, kad jauni žmonès pirmiausia išmoktų pažinti, didžiuotis ir vertinti savo krašto, regiono bei šalies paveldą, ir, peržengiant nacionalinių valstybių sienas, skatinamas europietiškojo tapatumo ịtvirtinimas, tai turètų būti vienas pagrindinių Lietuvos bei visos Europos kultūros politikos tikslų.

Atsižvelgiant ị kitų šalių ir Lietuvos paveldo edukatorių sukauptą patirtị straipsnyje siūlomas paveldo perteikimo moksleiviams modelis apima tiek geografinį, tiek ir vaikų amžiaus tarpsnių pjūvius, kurie tarpusavyje gali būti nuosekliai susieti.

Pirmuoju atveju rekomenduojama vietovès paveldo interpretacijos programą pradèti kurti remiantis minètu „koncentrinių ratų“ principu - nuo artimiausios vaiko aplinkos, jo namų ir šeimos, mokyklos, kuri, beje, pati gali būti istorinis pastatas ir t. t., einant tolyn iki kaimo / miestelio / miesto, regiono, nacionalinių, europinių ar pasaulinès vertès objektų bei vietovių Lietuvoje ar užsienyje lankymo ir pažinimo.

Tuo tarpu atsižvelgiant i j amžiaus tarpsnių psichologiją ir moksleivių turimas žinias paveldo edukacija, pasitelkiant paveldą, turètų būti pradedama skatinant jaunesnio amžiaus vaikus sudaryti savo šeimos genealoginị medį, rengiant pristatymus ar parodèles, dedikuotas jiems didžiausią autoritetą turinčių artimujų garbei bei atliekant projektèlius, pristatymus bei kuriant parodèles, skirtas jų gyvenamojo namo / vietos istorijai atskleisti. Vyresnio amžiaus vaikai galètų rengti projektus ar būti skatinami patys tapti gidais Europos paveldo dienų ar kitų paveldošvietos renginių metu, vietos bendruomenei pristatant savo gyvenamojo miesto mikrorajono, miestelio, gyvenvietès ar konkretaus paminklo istoriją, akcentuojant reikšmingiausių gamtos ir kultūros vertybių ypatumus (bažnyčia, dvaro sodyba, parkas, kapinės, mitologinės, archeologinès ar memorialinès vietos, išlikę tarpukario pastatai ar sovietmečio masinès gyvenamosios statybos kvartalai, viešieji monumentai, gatvèvardžiai, memorialinès lentos ir t. t.). Šiuos objektus pageidautina ne tik išmokyti atpažinti, suprasti ir vertinti, bet ir susieti su platesne valstybės ar meno raidos istorija. Gebėti atsakyti i klausimus: kuo mano gyvenamoji vieta ypatinga; kokie istoriniai įvykiai / procesai čia vyko; kokios žymios istorinès asmenybės čia gimè, gyveno ir kūré; kaip mano protėviai, seneliai ir tėvai susiję su Lietuvoje ir regione vykusiais istoriniais procesais bei ịvykiais, kuriuose iš jų jiems teko dalyvauti? Čia galètų padèti artimiausių 
piliakalnių ar pilkapių žvalgybiniai tyrimai, išvykos ị miestelio kapines, ieškant žymesnių krašto žmonių kapų, užduotis pasitelkus ikonografijos žodyną vietos bažnyčioje atpažinti paveiksluose ir skulptūrose pavaizduotus šventuosius ir t. t. Vyresniụjų klasių moksleiviai jau būtų skatinami aplankyti savo bendraamžius kito etnografinio regiono mokykloje, susipažinti su jo etnokultūriniais ypatumais ir papročiais. Per atostogas galètų būti lankomos nacionalinio, europinio ar UNESCO Pasaulio paveldo sąrašo vietovès Lietuvoje ar, esant finansinei galimybei, su lituanistiniais siužetais susijusios vietos kaimyninėse šalyse (Latvijoje ir Estijoje, Baltarusijoje, Ukrainoje, Lenkijoje, Rusijos federacijos Kaliningrado srityje ir t. t.). Svarbu, kad tirdami savo miestelio ar miesto istoriją vaikai būtų skatinami atkreipti dėmesị ị čia gyvenusių ar tebegyvenančių kitų tautų materialųji palikimą ir mokytųsi jị (at)pažinti bei vertinti. Galiausiai paskutinių klasių gimnazistai gali būti ịtraukiami ir ị ekskursijas, viktorinas, protmūšius, orientacinius žaidimus ar konkursus, kuriuose būtų gvildenami ir „nebesančio“ (sunaikinto, išnykusio tiek materialaus, tiek ir nematerialaus) ar „disonuojančio“, ginčytino, pavyzdžiui, carinio, sovietinio, paveldo klausimai. Nereikètų pamiršti ir nematerialaus paveldo (etninès muzikos, šokių, tautodailès ir t. t.), tradiciškai pasitelkiamo per religines ir kalendorines šventes ar atmintinų datų minejjimus ir pan., moksleivių ugdymui teikiamų galimybių. Tai, be abejo, tradiciškai ịtraukiama ị bendrąsias ugdymo programas, o ši veikla plètojama ịvairiuose renginiuose ir būreliuose. Tačiau reikia turèti omenyje, kad skirstymas ị ,,materialų“ ir „nematerialų“ paveldą šiandien jau laikomas pasenusiu (Munjeri, 2007: 323), tad vykdant ugdymo, pasitelkiant paveldą, veiklą būtina ieškoti integralios prieigos formų. Todèl patartina ị tradicijų perimamumo vyksmą labiau ịtraukti senjorus ir kitus vietos bendruomenès atstovus, kurie kartu su moksleiviais galètų paieškoti šiuolaikiškesnių spalvų bei sąskambių, taip aktualizuojant ir gaivinant šį neišsemiamos tautinès kultūros aruodą.

Edukacijai, pasitelkiant paveldą, tobulinti ir praktiškai diegti būtinos sutelktos, sisteminès bei nuoseklios susijusių sričių specialistų (pedagogų, paveldosaugininkų, muziejininkų, nevyriausybinių paveldo aktyvistų, kraštotyrininkų ir t. t.) pastangos, ši sritis turi būti integruota į moksleivių švietimo sistemą per įvairias formaliąsias ir neformaliąsias veiklas.

\section{Literatūra}

Allard, M. (2000). Le musée, agent de changement en éducation. Les musées en mouvement. Nouvelles conception, nouveaux publics (Belgique, Canada). Ed. par S. Jaumain. Bruxelles: Editions de l'ULB, p. 121-130.

Ashworth, G. J., Hartmann R. (2009). Žmogiškosios tragedijos ir siaubo vietų vadyba. Gamtos ir kultūros paveldas. Perteikimas ir ugdymas. Sud. R. Čepaitienè. Vilnius: Eugrimas.

Ashworth, G. J., Howard, P. (2008). Europos paveldas. Planavimas ir valdymas. Vilnius: Versus aureus.

Beck, L., Cable, T. (1998). Interpretation for the 21st Century: Fifteen Guiding Principles for Interpreting Nature and Culture. Urbana: Sagamore Publishing.

Bloom, B. S., Engelhart, M. D., Furst, E. J., Hill, W. H., Krathwohl, D. R. (1956). Taxonomy of educational objectives: The classification of educational goals. Handbook I: Cognitive domain. New York: David McKay Company.

Copeland, T. (2009). Archaeological Heritage Education: Citizenship from the Ground Up. Treballs d'Arqueologia, Vol. 15, p. 9-20.

Craig, B. (1989). Interpreting the Historic Scene: The Power of Imagination in Creating a Sense of Historic Place. Heritage Interpretation, Vol. 1, p. 107-112. London: Belhaven Press.

Čepaitienè, R., Mikailiené, Ž. (2017). Pasaulis prasideda čia. Paveldo ugdymo principai mokyklinio amžiaus vaikams. Vilnius: Didakta.

Čepaitienè, R. (2010). Paveldosauga globaliajame pasaulyje. Vilnius: LII.

The ICOMOS Charter for the Interpretation and Presentation of Cultural Heritage Sites (Ename Chareter). (2008). Prieiga internete: http://www.enamecharter.org/

Grappin, S., Jurion de Waha, F. (2007). Teaching, Remembrance and Cultural Heritage: Aushwitz-Birkenau Art Workshop. Heritage Education for Europe. Outcome and perspective. Ed. by L. Branchesi. Roma: Armando, p. 169-174.

Ham, S. (1992). Environmental Interpretation: A Practical Guide for People with Big Ideas and Small Budgets. Golden, CO: North American Press.

Harrison, R. (2013). Heritage. Critical Approaches. London: Routledge.

Heritage Education Handbook. (1986). Ed. by M. Dyer. Fleet, Hant, Heritage Education Trust.

Heritage in the Classroom: A Practical Manual for Teachers. (2005). Ed. by V. De Troyer. Antwerp: Garant.

Howard, P. (2003). Heritage: Management, Interpretation, Identity. London: MPG Books Ltd. 
Holcomb, B. (1998). Gender and Heritage Interpretation. Contemporary Issues in Heritage and Environmental Interpretation. Ed. by D. L. Uzzell, R. Ballantyne. London: The Stationary Office, p. 37-55.

Johnson, P. Thomas, B. (1995). Heritage as Business. Heritage, Tourism and Society. Ed. by D. T. Herbert. London: Mansell, p. 170-190.

Light, D. (1995). Heritage as Informal Education. Heritage, Tourisme and Society. Ed. by D. T. Herbert. London: Mansell, p. 117-145.

Munjeri, D. (2007). Tangible and intangible Heritage: from Difference to Convergence, Cultural Heritage. Critical Concepts in Media and Cultural Studies, Vol. 4, p. 323-330. London: Routledge,

Prentice, R. C. (1995). Heritage as formal Education. Heritage, Tourisme and Society. Ed. by D. T. Herbert. London: Mansell, p. 146-169.

Silberman, N. (2013). Heritage Interpretation as Public Discourse: Towards a New Paradigm. Understanding Heritage. Berlin: DeGruyter.

Tilden, F. (1977). Interpreting our Heritage. Chapel Hill, N. C.: University of North Carolina Press.

Uzzell, D. (1998). Interpreting Our Heritage: A Theoretical Interpretation. Contemporary Issues in Heritage and Environmental Interpretation: Problems and Prospects. London: The Stationery Office.

\title{
THE FACTOR OF TOURISM IN HERITAGE EDUCATION OF SCHOOLSTUDENTS
}

\author{
RASA ČEPAITIENĖ \\ The Lithuanian Institute of History (Lithuania)
}

\section{Summary}

Cultural heritage encompasses what a particular group of people has in common that makes them different from others. However, the erosion of traditional cultural norms and customs, disregard of national and local heritage and culture, under-funding of heritage sites, cultural intolerance and experts' incompetence, even conscious or unconscious vandalism are among the challenges hindering heritage conservation in contemporary Lithuania. The article analyses the possibility to deal with all these problems. Heritage education and interpretation could be an effective solution and a good approach to teaching and learning about history that uses information available from the material culture and the human and artistic achievements, local technologies, as well as social and economic contribution of diverse groups of people. As the younger generation is increasingly distancing itself from its culture, so inclusion of heritage education as part of the school curriculum seems the best way to make sure school students will learn about their heritage.

The use of heritage in educational settings can serve a variety of implicit and explicit objectives: it can stimulate students not only to appreciate particular heritage or identify themselves with certain historical places, facts and actors and an appropriate national 'grand narrative', but also to develop their historical knowledge and understanding of continuity and change processes, and also, the cause and consequence. Some objectives even aim at developing students' competency to de-construct such narratives and formulate historical questions based on their own curiosity.

This variety of objectives generates a whole range of heritage education principles and practices which are discussed in this article. Museum artefacts, buildings, monuments, traditions, customs, folk stories and other 'heritage' traces can be powerful resources for learning and teaching in the classroom and beyond it. The practice of integrating these sources into education via heritage presentation and interpretation based on 'good examples', needs to be discussed and improved seeking to reach broader educational goals and competences. As the term implies, informal heritage education and cultural heritage tourism involves visiting places that are significant to the past or present cultural identity of a particular group of people. Cultural 
heritage tourism provides an opportunity for people and especially for young children to experience their local, regional and national culture in depth, whether by visiting attractions, historical or culturally relevant places, or by taking part in different cultural activities. The main idea of the article is that heritage education, which generates such important social, economic and political benefits, must be included into the Lithuanian education system and be introduced in the primary and secondary schools' curriculum more broadly and consistently.

KEYWORDS: heritage, education, interpretation, tourism, school students.

JEL CODES: I. 12. 120. 